\title{
Characterization and genesis of waterfalls of the Presidente Figueiredo region, northeast State of Amazonas, Brazil
}

\author{
AFONSO C. R. NOGUEIRA ${ }^{1,2}$ and ROSEANE R. SARGES ${ }^{1 *}$ \\ ${ }^{1}$ Departamento de Geociências, Universidade do Amazonas, Campus Universitário \\ 69077-000 Manaus, AM, Brasil \\ ${ }^{2}$ Programa de Pós-graduação em Geologia Sedimentar Igc-USP \\ Departamento de Geologia Sedimentar e Ambiental-Igc/USP \\ Rua do Lago, 562 - 05508-000 São Paulo, SP, Brasil
}

Manuscript received on August 30, 2000; accepted for publication on February 12, 2001;

presented by K. Suguio

\begin{abstract}
The waterfalls of the Presidente Figueiredo municipality represent a fascinating natural scenery of northeast state of Amazonas, northern Brazil. The falls, generally less than 10m high, are developed on siliciclastic rocks of the Nhamundá (Lower Silurian), and Manacapuru (Upper Silurian - Lower Devonian) formations. Morphological and structural analyses of these features indicate that most of them originated through Quaternary neotectonics and are installed in NE-trending normal fault escarpments. Waterfalls also developed within pseudokarstic features, but are less frequent.

The origin of the Presidente Figueiredo waterfalls probably goes back to the Neogene, when the region was submitted to laterization processes associated with a humid climate and a dense rainforest. These conditions favored the development of caves in quartzarenites of the Nhamundá Formation. During the Quaternary, the region was subjected to NE-trending normal faulting which displaced laterite layers, rivers and streams giving rise to waterfalls. These climatic and tectonic phenomena promoted intense relief dissection, as indicated by fault escarpment retreat and cave dismantlement, responsible for the present-day morphologic configuration.
\end{abstract}

Key words: waterfalls, Western Amazon, Quaternary tectonics, pseudokarst.

\section{INTRODUCTION}

The Presidente Figueiredo municipality, located about $100 \mathrm{~km}$ to the north of Manaus and easily accessible by the BR-174 and AM-240 highways, represents one of the major tourist attractions of the northeast state of Amazonas (Fig. 1). It is mainly due to their natural beauties represented by exuberant fauna and flora, caves, rapids and waterfalls. Founded in 1981, this municipality has an area

Correspondence to: Afonso C.R. Nogueira

E-mail: acrnogue@usp.br

${ }^{*} \mathrm{CNPq}$ undergraduate fellowship of $24.781 \mathrm{~km}^{2}$, where the Urubu and Caverna do Maroaga Environmental Protection Areas, WaimiriAtroari Indigenous Reserve and most of the Uatumã Biological Reservation are located.

Presidente Figueiredo region is known as "Waterfallsland", however its geological and geomorphological settings are still little known, mainly concerning to the origin of their nowadays known 57 waterfalls.

The morphological and structural analyses were conducted on 16 waterfalls, using satellite images TM/LANDSAT-5, band 4, WRS 230/61 
and 231/61 (scale 1:100,000), planialtimetric charts (scale 1:100,000), radar images (scale 1:250,000) and aerial photographs numbers 20659 to 20669 of DNPM/CPRM (scale 1:100,000). This study allowed to conclude that the waterfalls, developed in quartzarenites and shales of the Nhamundá (Lower Silurian) and Manacapuru (Upper Silurian-Lower Devonian) formations, are associated to fault scarps and secondarily to pseudokarstic features.

\section{THE PRESIDENTE FIGUEIREDO REGION}

\section{Morphologic and Litostratigraphic Setting}

The Presidente Figueiredo region, located along northern border of the Amazon Basin, is included within the Amazon Sedimentary Basin Plateau (ASBP) and Rio Trombetas-Rio Negro Dissected Plateau (TNDP) (Nascimento et al. 1976, Costa et al. 1978). The ASBP, the most expressive physiographic feature at the north of the study area, is developed on older rocks and consists of 100 to $250 \mathrm{~m}$ high flat-topped hills (tablelands), gently-sloping valleys and low to medium drainage density. The TNDP domain constitutes a large southward gently dipping planation surface, partially formed by 150-250m high ferrobauxite-capped round-topped hills. This relief is recognized by interfluvial tablelands and narrow steeply-sided valleys, forming an intensely dissected surface with medium to high drainage density.

The older lithostratigraphic units of the area are Precambrian in age (Fig. 1). The Uatumã Supergroup is composed by acid volcanic rocks, granites and basic to intermediary dikes (Santos 1984) which, together with Prosperança Formation siliciclastic rocks, constitutes the Proterozoic basement of the northern margin of the Amazon Basin (Cunha et al. 1994, Nogueira and Soares 1996).

Three lithostratigraphic units of Trombetas Group have been recognized in the Presidente Figueiredo region: 1) Nhamundá Formation (Lower Silurian; Grahn 1991, 1992), that consists of fine to coarse-grained quartzarenites with cross and planar beddings, and subordinated shales (Cunha et al.
1994, Nogueira et al. 1997, Soares et al. 1998); 2) Pitinga Formation (Lower to Middle Silurian; Grahn 1991, 1992), represented by shales and fine-grained sandstones with wavy bedding (Cunha et al. 1994, Nogueira et al. 1997); and 3) shales and subordinated sandstones of the Manacapuru Formation (Upper Silurian to Lower Devonian; Grahn 1991, 1992, Coelho 1994), that are exposed at east-western belt outlining approximately the Urubu River valley.

The Alter do Chão Formation (Upper Cretaceous; Dino et al. 1999), confined in grabens (Nogueira et al. 1997) or as continuous outcrops to the south of the studied area, is composed of feldspathic-kaolinitic sandstones, conglomerates and subordinated mudstones (Cunha et al. 1994, Nogueira et al. 1997).

At the top of Precambrian residual massifs and older sedimentary units occurs Tertiary-Quaternary Cover. This unit consists of Late Tertiary to Pleistocene mature and immature lateritic profiles and yellow latosols (Costa 1991, Horbe et al. 1997, 2000) and Quaternary colluvial and alluvial deposits.

\section{Hydrographical and Structural Setting}

The Urubu and Uatumã rivers represent the main streams of hydrographic basin of the Presidente Figueiredo region flowing preferentially to the SE (Figs. 1 and 2). The rivers exhibit dendritic to subdentritic patterns with a parallel arrangement of streams, mainly within major lineaments concentration area, with some segments entrenched within faults and locally developing elbow-like anomalies (Fig. 2). The waterfalls are more frequent at the upstream reaches and the most famous are related to the Urubuí, Mutum, dos Veados and Lajes rivers (Fig. 2). However, the falls are not always associated to larger streams, sometimes being found in first to second order tributaries (Fig. 2). The rivers discharge variations modify the waterfall profile twice a year. From December to May, the discharge is maximum due to high precipitation, while from June to November the rivers present a minimum water volume. 

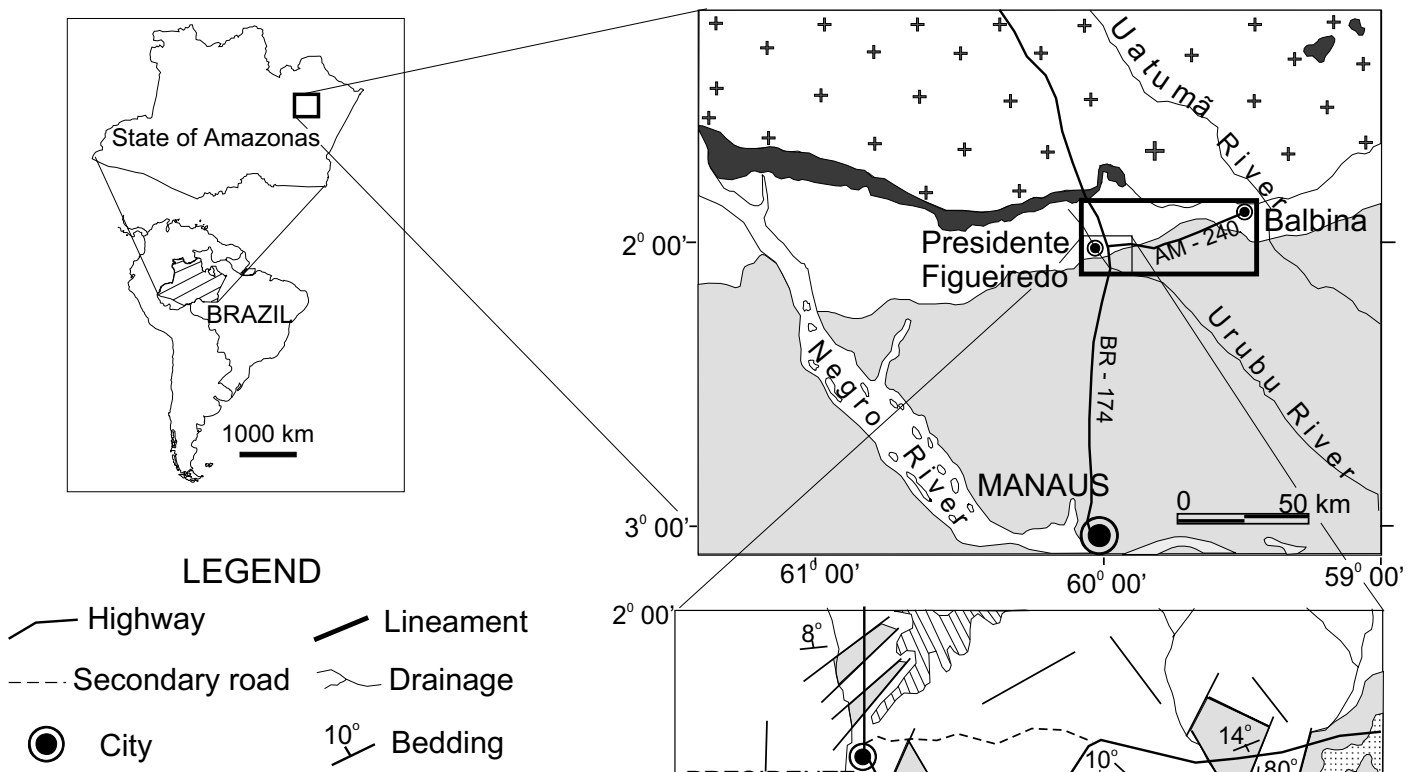

\section{LITHOSTRATIGRAPHY}

\section{Tertiary-Quaternary Cover}

Alter do Chão Formation (Cretaceous)

Manacapuru Formation (Silurian - Devonian)

Pitinga Formation (Silurian)

$\square$ Nhamundá Formation (Silurian)

Prosperança Formation (Neoproterozoic)

++ Uatumã Supergroup (Mesoproterozoic)

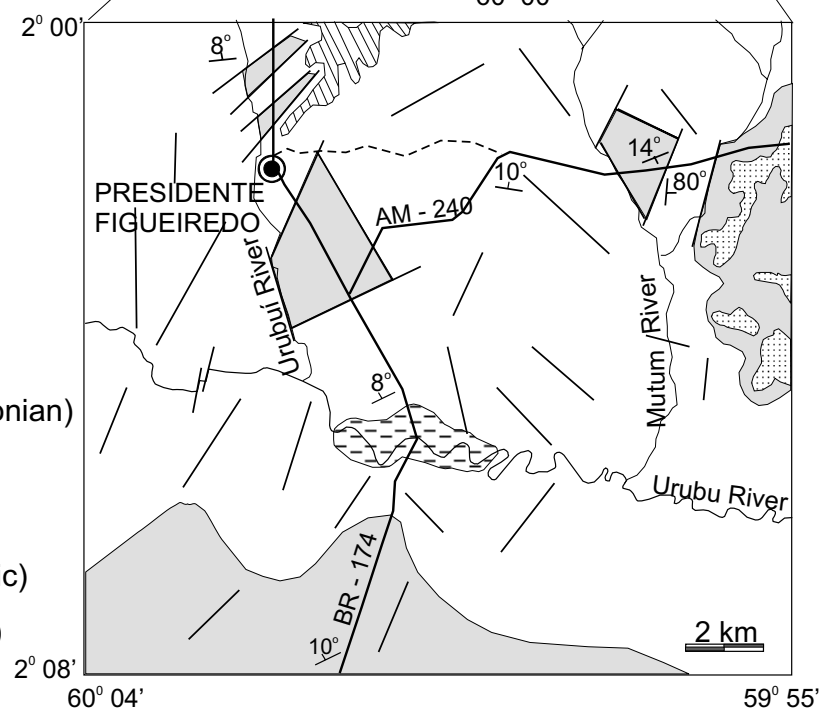

Fig. 1 - Location and geologic map of the Presidente Figueiredo municipality and the study area. (After Schobbenhaus and Campos 1984 and Nogueira et al. 1997 modified).

The major identified-lineaments are trending preferentially to NE-SW and NW-SE, concentrated between $0^{\circ}-40^{\circ} \mathrm{NE}$ and $10^{\circ}-50^{\circ} \mathrm{NW}$. E-W and N$\mathrm{S}$ orientated lineaments are subordinated. Locally, the lineaments show romboedral-shaped patterns, formed by NE-SW and NW-SE conjugated sets, sometimes associated with right-lateral and leftlateral brittle strike-slip faults (Fig. 2).

The field surveys consisted mainly in the recognition of planar and linear rock structures, seeking to understand their geometry and age relationships. The commonly observed features in the waterfalls are faults and fractures plans with the same direction of the falls. The fault scarps have a NE-SW direction, dipping steeply to NW or SE, and show straight and subordinated slightly curved geometry (Fig. 3). As isolated faults, with up to $30 \mathrm{~m}$ of normal displacements, there is the Paredão Waterfall, or as composite stepped fault scarps like in Santa Cláudia, Onça, Iracema, Araras and Suçuarana waterfalls (Fig. 3). The normal component of these discontinuities have been inferred by bed displacements, and by scarce and little preserved steeply dipping striations. 


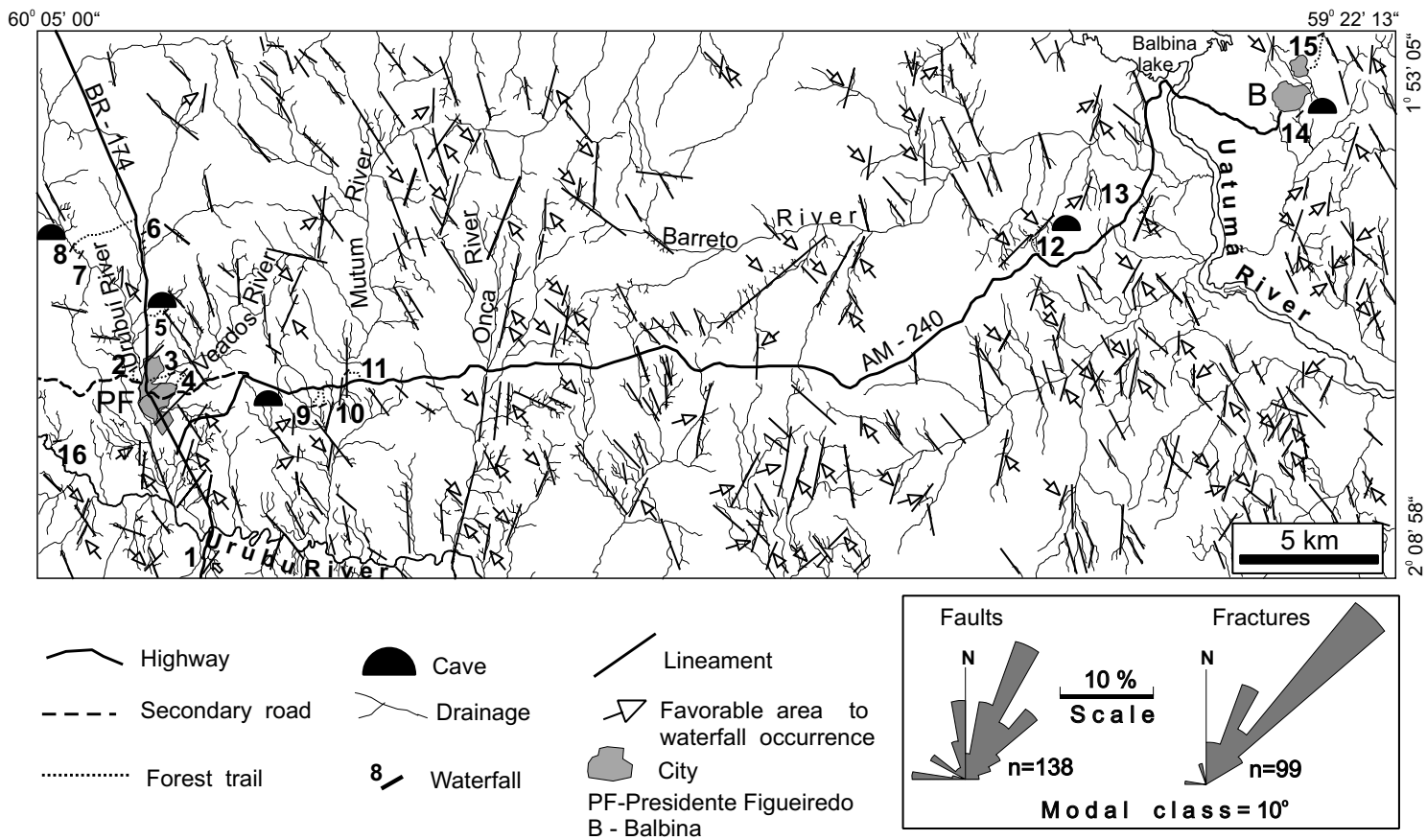

Fig. 2 - A drainage and lineament map of the study area, showing favorable areas for occurrence of waterfalls (arrows). The numbers on the map correspond to the waterfalls: 1) Suframa; 2) Onça; 3) Santa Cláudia; 4) Orquídeas; 5) Arcos; 6) Lajes; 7) Araras; 8) Iracema; 9) Berro D’Agua; 10) Santuário; 11) Portal das Cachoeiras; 12) Pedra Furada; 13) Paredão; 14) Bica; 15) Suçuarana, 16) Rio Branquinho. The rose diagrams in the lower right of the map show the faults and fractures measured in the studied waterfalls.

The Nhamundá Formation, in general, exhibits subhorizontal bedding, but near the faults it can be subvertical (Figs. 1 and 4A and B). Discrete strikeslip faults trending NE-SW and NW-SE, with left and right-lateral displacements, respectively, are locally observed in the Suframa, Araras and Suçuarana waterfalls. The fractures are normally straight, sometimes curvilinear, and oriented to NE and NW and secondarily N-S, dipping subvertically near the faults.

The identified mesoscale normal fault trend was extended to the NE-SW lineaments recognized on satellite images. The interception between lineaments and drainage traces were considered to be favorable for occurrence of waterfalls. Using this hypothesis it was possible to delineate a drainage and lineaments map, which is useful for discovery of new waterfalls (Fig. 2).

\section{THE WATERFALLS OF PRESIDENTE FIGUEIREDO}

\section{MORPHOLOGY}

The waterfalls of Presidente Figueiredo region are small-scale morphologic features, in general less than $6 \mathrm{~m}$ high and rarely more than $10 \mathrm{~m}$ high (Table I). They are developed on thick quartzarenites layers of the Nhamundá Formation and, secondarily, on quartzarenites and mudstones of the Manacapuru Formation. The rivers entrapped within waterfalls usually flow on horizontal layers although, locally, as in the Portal das Cachoeiras, the waterfall is obsequent (flowing against the dip) and running toward the subsequent (flowing normally to the dip) Mutum River (Fig. 4B).

Most of the waterfalls of the Presidente Figueiredo region are composed by the following morphologic elements (Fig. 5): 1) waterfall, 2 to $30 \mathrm{~m}$ high with a rocky bed (Fig. 3); 2) large-scale pot hole 

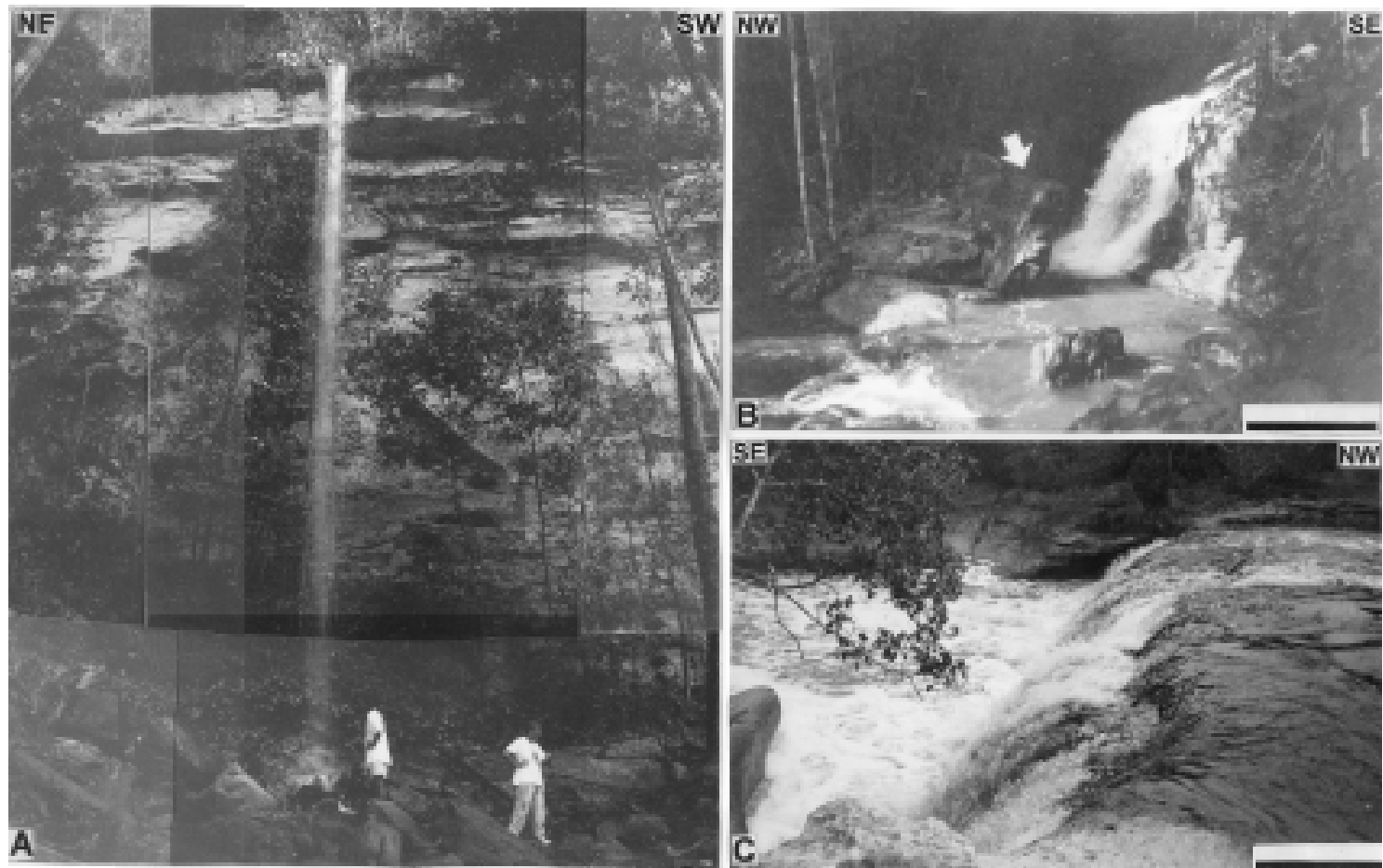

Fig. 3 - General aspects of fault scarps. A) Paredão Waterfall. B) Onça Waterfall, showing a rock slice detached from the fault plain (arrow). C) Fall preceeding the Iracema Waterfall. Scale bar is $3 \mathrm{~m}$.

\section{TABLE I}

Main characteristics of the studied waterfalls.

\begin{tabular}{|c|c|c|c|c|c|c|c|c|c|c|}
\hline \multirow{2}{*}{$\begin{array}{l}\text { Waterfall/ } \\
\text { Height }(\mathrm{m})\end{array}$} & \multicolumn{2}{|c|}{ Lithology } & \multicolumn{8}{|c|}{ Structure/Morphology Feature } \\
\hline & Sandstone & Mudstone & Stratification & $\begin{array}{l}\text { Trace } \\
\text { fossil }\end{array}$ & Scarp & $\begin{array}{c}\text { Honey- } \\
\text { comb }\end{array}$ & $\begin{array}{r}\text { Pot } \\
\text { hole }\end{array}$ & $\begin{array}{l}\text { Sink } \\
\text { hole }\end{array}$ & Cave & Cracks \\
\hline Araras / 8 & $*$ & & $*$ & & & & $*$ & & & \\
\hline $\operatorname{Arcos} / 1,5$ & $*$ & & $*$ & & & & & & $*$ & \\
\hline Berro D’Água / 2,5 & $*$ & & & & & & & & & \\
\hline Bica / 4 & $*$ & & & & & & & & $*$ & \\
\hline Iracema / 10 & $*$ & & $*$ & & $*$ & $*$ & $*$ & & $*$ & $*$ \\
\hline Lajes / 1,7 & $*$ & & $*$ & $*$ & $*$ & & $*$ & & & $*$ \\
\hline Onça / 5 & $*$ & & $*$ & & * & & & & & \\
\hline Orquídeas / 6 & $*$ & & * & $*$ & & & & & & \\
\hline Paredão / 30 & $*$ & & $*$ & & $*$ & & & & & \\
\hline Pedra Furada / 6 & $*$ & $*$ & * & $*$ & & & & $*$ & $*$ & \\
\hline Portal das & & & & & & & & & & \\
\hline Cachoeiras / 3 & $*$ & & $*$ & $*$ & & $*$ & & & & $*$ \\
\hline Santa Cláudia / 4 & $*$ & $*$ & $*$ & $*$ & & & $*$ & & $*$ & \\
\hline Santuário / 15 & $*$ & & $*$ & & $*$ & & & & & \\
\hline Suçuarana / 12 & $*$ & & $*$ & & & & $*$ & $*$ & & \\
\hline Suframa / 6 & $*$ & $*$ & * & $*$ & & & & & & \\
\hline Rio Branquinho & $*$ & & & & $*$ & & & & & \\
\hline
\end{tabular}



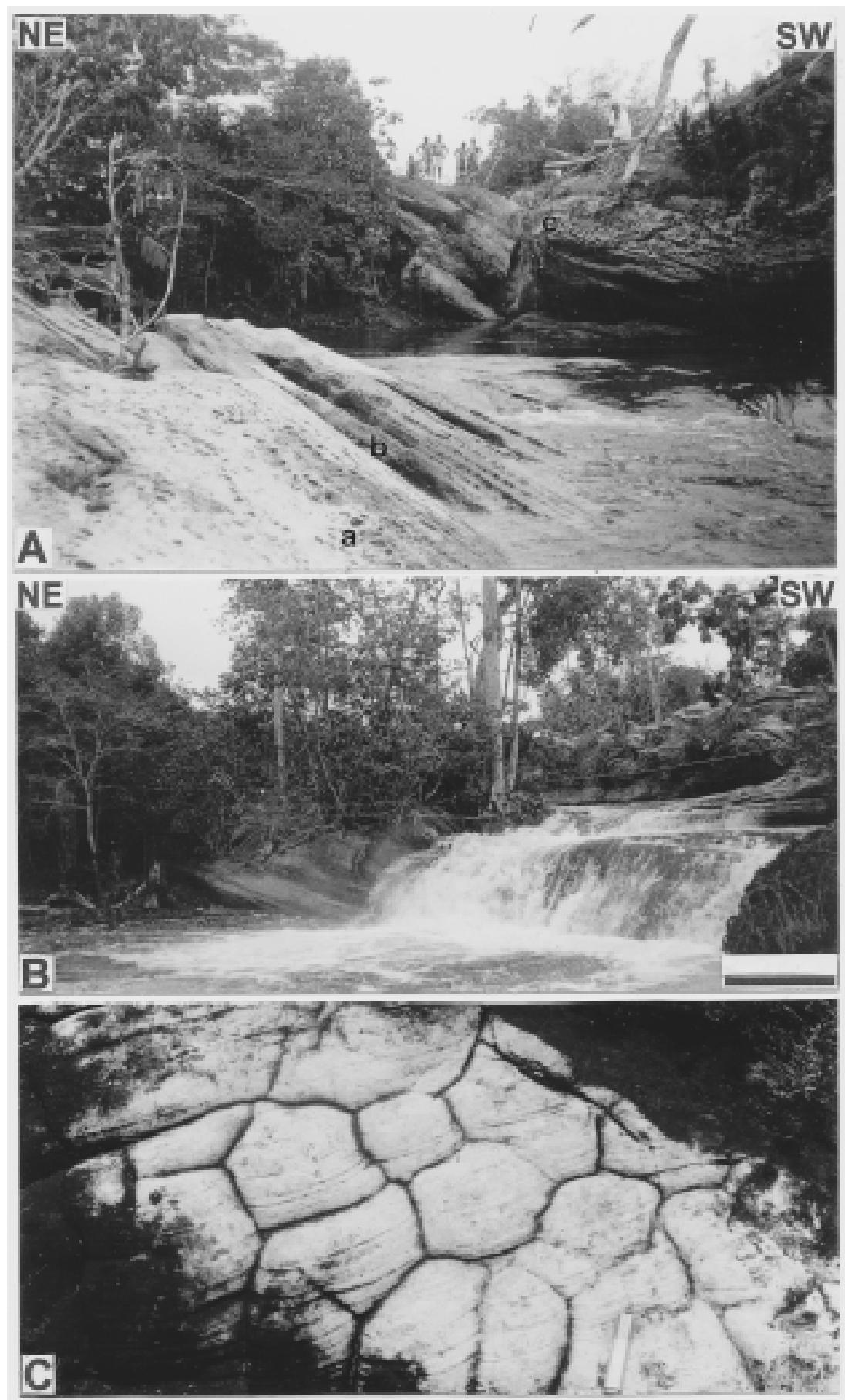

Fig. 4 - Morphologic aspects of the Portal das Cachoeiras Waterfall. A) The subsequent behavior of the Mutum River flowing on rotate beds of the Nhamundá sandstones. The letters "a", "b" and "c" refer, respectively, the pot hole feature, Skolithos-like traces detached by erosive water action, and honeycomb structure. B) Obsequent main fall (flow contrary to the dipping). Scale bar is $3 \mathrm{~m}$. C) Polygonal cracks. 
(or natural swimming pool), scoured at the base of the waterfall by impact of water, enlarged by rocky fragments transported by the river (Fig. 4B); 3) roof, restricted to waterfalls with layers more resistant to erosion, which is situated at the top of waterfall; 4) and scarp (or wall), representing the fault plane more or less retreated by water erosion (Fig. 3). The main characteristics of the studied waterfalls are summarized in Table I.

At the bottom and margin of rivers with waterfalls there are smaller pot holes (Fig. 4Aa). Sometimes, they have been developed following Skolithos-like traces and fractures, as in the Urubuí River rapid in Presidente Figueiredo town or in the Lajes, Iracema and Portal das Cachoeiras waterfalls (Fig. 4Ab). There are also sandstones with honeycomb solution features, which sometimes confused with pot holes, besides tortoise shell-like polygonal cracks are found in Iracema, Portal das Cachoeiras and Lajes waterfalls (Figs. 4Ac and 4C). Sink hole morphology was found mainly on waterfall roof resistant layers. Its cylindrical shape, where the stream is beheaded, sometimes is tilted up to $45^{\circ}$ in relation to the subhorizontal roof (Fig. 6). In Suframa and Pedra Furada waterfalls, centimetric layers of silicified-sandstone, form a positive relief on the wall of finer material with a stepped pattern (Fig. 6A).

The standard morphology of the waterfalls (Fig. 5) is suitable to the waterfalls formed in fault scarps; however, it could not be applied to the waterfalls controlled by pseudokarstic relief features. The morphology of the Arcos Waterfall area is characterized by three quartzarenite biconvex projections, whose convexities (arches) are cylindrical with a diameter of $3 \mathrm{~m}$ and length of $14 \mathrm{~m}$, distant themselves by $12 \mathrm{~m}$ (Fig. 7). The central part of these biconvexities forms an elliptical outlet channel with a diameter of 1 to $6 \mathrm{~m}$, that can be active or abandoned. The active outlet is draining the stream to form the main fall of the Arcos Waterfall. In contrast, the abandoned outlet rises about $2,5 \mathrm{~m}$ above the water level and, sometimes, form natural bridges on the river (Fig. 7).

\section{ORIGIN}

The geological control of waterfalls is well known, and usually they represent a significant evidence for faulting or fracturing (Schwarzbach 1967, Philbrick 1970, Barcha and Arid 1975, Young 1985, Deffontaines and Chorowicz 1991, Alexandrowicz 1994). On the other hand, erosional action of waters upon beds of different resistance degrees and the underground rivers surging can also generate waterfalls (Holmes 1966, Schwarzbach 1967, Christofoletti 1974, 1981, Coltrinari 1994). The occurrence of normal faults and fractures, usually with the same direction of the wall of the falls, the presence of stratigraphic displacements and of the tilted beds (Figs. 3 and 4) suggest that the Presidente Figueiredo waterfalls were mainly controlled by tectonics. The juvenile nature of the rivers truncated by the NESW fault and/or lineaments, incised within rocks of the Nhamundá and Manacapuru formations, without floodplains, as well as displacements of TertiaryQuaternary lateritic levels developed on Late Cretaceous rocks (Fig. 1), suggest that Quaternary tectonics generated these features. The importance of NESW and NW-SE trending lineaments in the Amazonian region, as identified in this work (Fig. 1), was firstly recognized by Sternberg (1950) and corroborated by several authors (Franzinelli and Igreja 1990, Costa et al. 1993, Costa et al. 1996). Particularly in the studied area, Nogueira et al. (1997) recognized these trend controlling graben structures that confine the Cretaceous sediments of the Alter do Chão Formation, and promote vertical displacements of Upper Tertiary-Quaternary lateritic profiles. The neotectonic studies carried out in the Amazonian region have been developed in order to characterize these tectonic movements (Costa et al. 1988, Franzinelli and Piuci 1988, Franzinelli and Igreja 1990, Silva et al. 1994, Costa et al. 1996, Fernandes Filho et al. 1997). This event has been attributed to the displacement of the South American Plate to west since the Miocene (Costa et al. 1996). In this model, that suggest the action of an intraplate right-lateral binary, the normal neotectonic faults 




Fig. 5 - Morphological elements of waterfalls (after Coltrinari 1994).

of western Amazonian would be oriented to NWSE and NNW-SSE, differently from the directions founded in the waterfalls. In addition, the NE-SW direction in this model would represent reverse or strike-slip faults. The field data from 16 outcrops are not enough to solve this incompatibility nor to adopt the above mentioned neotectonic model in this work, but apparently are sufficient to discard the association of these waterfalls with reverse faults.

The erosional action of the water, of subsidiary importance in the waterfalls originated by faults, was responsible for the headward erosion suitable for the scarp retreat, which is function of the resistance, thickness and fracturing degree of the layers (Alexandrowicz 1994). The mechanical fracturing is one of the most important processes for the wall degradation because it favors fast removal of blocks and rocks fragments, whose transport increase erosional ability of the turbulent flow. In waterfalls formed only by more resistant beds, the headward erosion is less effective, unlike those developed upon mudstone and sandstone successions. The removal of the finest material of these successions leads to the formation of multiple stepped pattern, where the projecting parts are formed by sandstone layers (Fig. 6A).

The turbulent flow, at the waterfall base, associated with rocky fragments, is the main agent in sculpturing varied erosional features (Suguio and Bigarella 1990). The natural abrasive agents, as pebbles and sands, increase the erosional power of the water acting on the waterfall rocky wall and on the river bed, becoming the mechanism responsible for the formation of pot holes and related structures (Ängeby 1951). Sometimes, deep erosion of the pot holes can perforate the resistant beds of the top, to generate sinks, where the river is partially beheaded as observed in the Pedra Furada and Suçuarana waterfalls (Fig. 6B). In the Pedra Furada Waterfall, one of these sinks was carved following fractures with dip of $45^{\circ}$ (Fig. 6B). Together with mechanical abrasion, chemical solution processes originated honeycomb features. The origin of the polygonal cracks (Fig. 4C) is still controversial, although it is assumed that the cracking occurred on a crust formed by secondary siliceous cement of sand grains, due to 

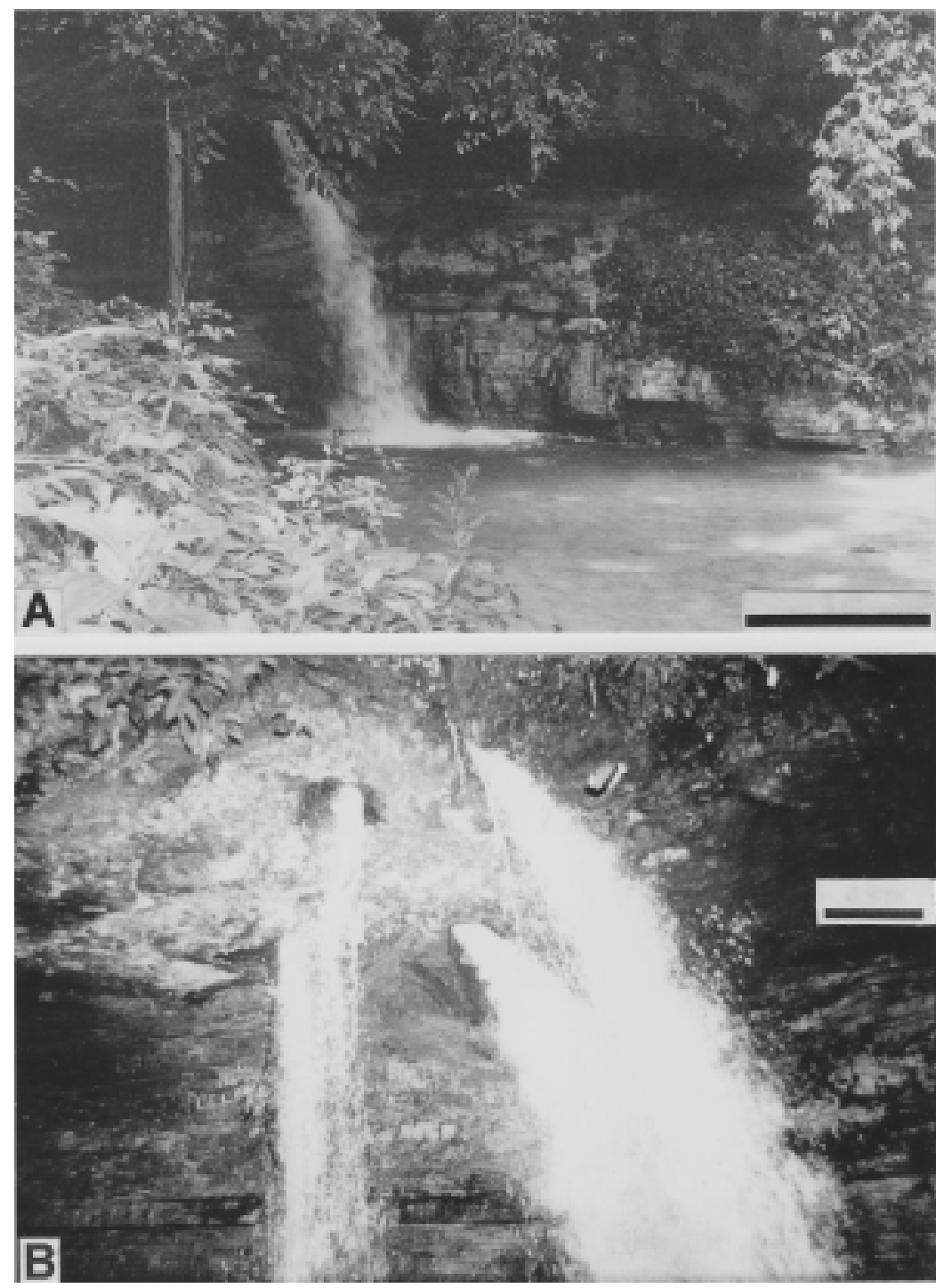

Fig. 6 - Pedra Furada Waterfall. A) The general aspects and rock of the wall represented by interbedded shales and basal stratified sandstones and massive sandstone in the top perforated by two sinks (dry period). Scale bar is $3 \mathrm{~m}$. B) Detail of the sinks (in plant) in flood period. Scale bar is $0,5 \mathrm{~m}$.

changes in the temperature and moisture (Robinson and William 1989).

The tectonic processes recognized in almost all of the studied waterfalls, cannot be applied to the origin of Arcos, Pedra Furada and Bica waterfalls. The features in arches, sheltered caves and outlet channels (Fig. 7) resemble to morphologic el- ements of pseudokarstic relief, common in the studied area (Fig. 2), being originated in part by dissolution and mainly by hydrodynamic removal of grains during the formation of these waterfalls. The higher position and the larger diameter of the abandoned in relation to the actives outlets of the Arcos Waterfall (Fig. 7B) indicate an intense rock rework- 

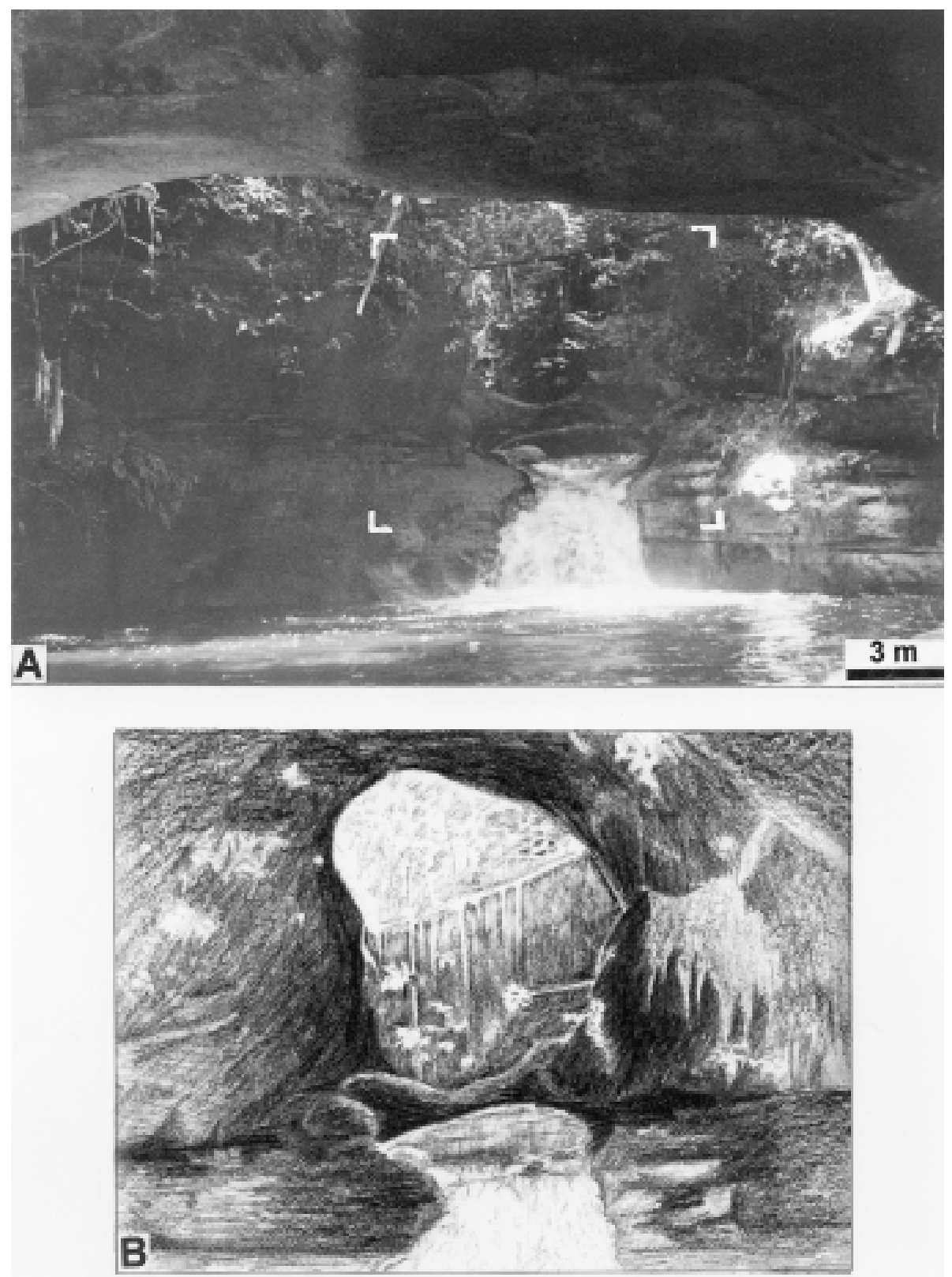

Fig. 7 - Panoramic view of Arcos Waterfall. A) In first plan, cylindrical convexity of quartzarenite (arch) is forming natural bridge on natural swimming pool. Evenly parallel bedding can be observed in at wall. The detached area refers the location of the figure 7B. B) Drawing of abandoned and active outlets (detail of the illustration 7A).

ing by underground rivers and a tectonic uplift of the area, after the formation of caves, with progressive drainage readjustment. The enlargement of the Arcos Waterfall outlet channels probably related to pipes occurred under phreatic conditions and can be explained by the piping/sanding model (Urbani 1986, Martini 1987, Corrêa Neto and Dutra 1997), and was just proposed by Karmann (1986) for the 
genesis of the Refúgio do Maroaga Cave.

The piping/sanding model assumes a base level stability and low gradient of the phreatic zone, associated to slow groundwater flow that favored partial dissolution of silica (White et al. 1966). As mentioned by Corrêa Neto and Dutra (1997), this dissolution could be most active through rock discontinuities giving rise to higher porosity and permeability zones where the rock would be mechanically weakened concentrating the water flow. The uplift of the area would increase the slope and the underground water flow speed, which increases mechanically the removal of the quartz grains and forms cylindrical pipes which would enlarge to form galleries and chambers. Most of the studies concerning to formation of caves in sandstone assumes an initial period of water table stability and subsequent uplift (Young 1986, Urbani 1986, Martini 1987). In the studied area, the relief dissection processes promoted collapse of the cave roofs resulting locally in a residual relief with inselbergs, as exemplified by the current morphologic configuration of the Arcos Waterfall area (Fig. 7).

\section{Evolution}

At the end of Neogene, the quartzarenites of Nhamundá Formation, in Presidente Figueiredo region, suffered chemical solution due to the phreatic zone stability, intensified by the action of humic acids supplied by rainforest vegetable remains (Fig. 8B1). The groundwater flow promoted the mechanical removal of the friable portions of sandstones, and led to the development of cave morphologic elements such as galleries, columns and sinks mainly controlled by older structural features (Fig. 8B2).

During the Quaternary, the Presidente Figueiredo region was affected by a brittle tectonic event that caused a drainage readjustment. NE-SW trending normal faults, generated during this event, sectioned the rivers fit in NW-SE trending lineaments, originating decametric to metric displacements and, eventually, bedding tilting in the Nhamundá Formation generating the waterfalls (Figs. 8A1 and 8A2). The uplifted blocks (horsts) imposed the va- dose zone to develop caves, causing subterranean rivers readjustments (Fig. 8B2). Local hollowing out and subsequent collapse of less resistant rocks along fault plans promoted scarps retreating (Fig. 8A3).

The intense morphologic dissection imposed by the climatic and tectonic phenomena contributed for the cave dismantlement. The continuity of the denudation processes led to the current configuration of the region, with areas locally exhibiting a residual relief where waterfalls was installed (Fig. 8B3).

\section{CONCLUSIONS}

The waterfalls of Presidente Figueiredo were formed, in general, by sectioning of rivers by NESW trending normal faults with metric displacement, supposedly of Quaternary age. However, some Quaternary waterfalls are controlled by a pseudokarstic relief, probably formed during the Late Tertiary-Early Quaternary, as well exemplified by the Arcos Waterfall.

The morphologic, geological and genetic differences observed in the studied waterfalls allowed the identification of two categories of waterfalls: developed from normal faults, exemplified by Suframa, Onça, Santa Cláudia, Lajes, Iracema, Araras, Orquídeas, Berro D’ Água, Santuário, Portal das Cachoeiras, Paredão, Suçuarana and Rio Branquinho waterfalls, and those controlled by pseudokarstic features, as exemplified by Arcos, Pedra Furada and Bica waterfalls.

The siliciclastic rocks of the waterfalls beds belong to the Nhamundá and Manacapuru formations of the Trombetas Group, whose ages have been attributed, respectively, to Upper OrdovicianWenlockian $( \pm 410 \mathrm{Ma})$ and Pridolian-Lochkovian $( \pm 400 \mathrm{Ma})$. However, it is known, in adjacent areas, occurrence of waterfalls developed in rivers flowing on Proterozoic igneous rocks of the Uatumã Supergroup.

The identification of lineaments and drainage interceptions, considered in this work as favorable 

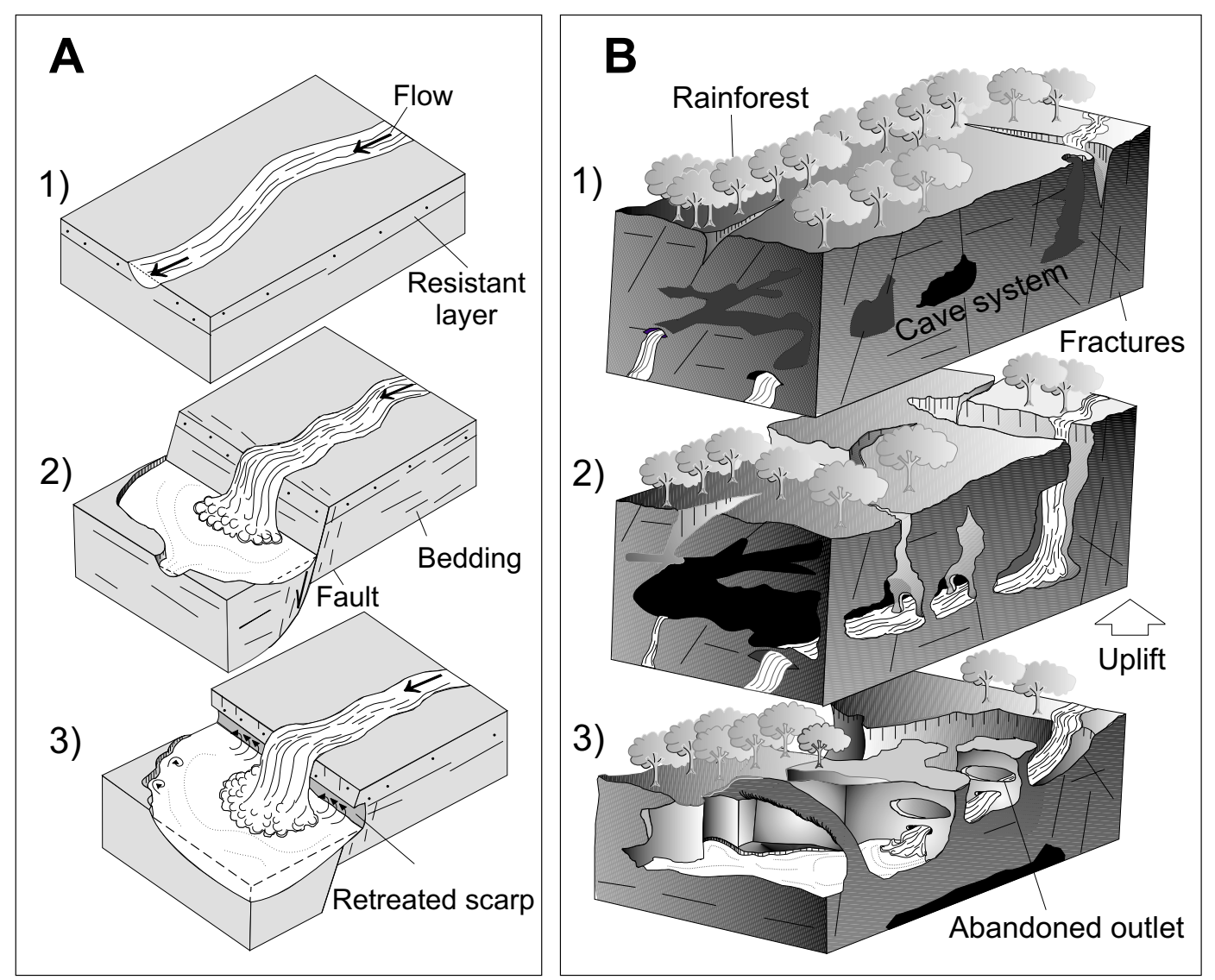

Fig. 8 - Block diagrams summarizing the evolution of the Presidente Figueiredo waterfalls. A) Waterfalls developed from normal faults: 1) Area before tectonism; 2) intersecting of rivers for normal faults, originating waterfalls; and 3) hollowing out and consequent collapse of the wall composed of weakened rocks, promoting escarpment retreat. B) Waterfalls controlled by pseudokarstic relief, exemplified by Arcos Waterfall: 1) Caves and pipes formed by dissolution and hydrodynamic removal in the phreatic zone; 2) uplift of the area and intensification of processes of cave formation and beginning of relief dissection 3) present configuration of the waterfall area, with ruiniform relief sculptured upon ancient pseudokarstic features.

areas to the waterfalls occurrence, can help in the discovery of new sites with this morphology, allowing an accurate evaluation of the touristic potential of the Presidente Figueiredo municipality.

\section{ACKNOWLEDGEMENTS}

The authors are grateful to Universidade do Amazonas, for the logistic and financial support and to CNPq by an undergraduate fellowship to the second author inserted in the "O Neocenozóico da Amazônia Ocidental" CNPq project (Grant no. 520243/986). Critical reviews by Kenitiro Suguio, Werner
Truckenbrodt, Clauzionor Silva, Claudio Riccomini, Alexei Kerkis and two anonymous referees are highly appreciated in the final text. Special thanks to Emílio Soares and Valmir Souza for discussions and field assistance.

\section{RESUMO}

As cachoeiras da região de Presidente Figueiredo constituem um dos mais fascinantes cenários naturais do nordeste do Estado do Amazonas, norte do Brasil. As quedas, geralmente com menos de $10 \mathrm{~m}$ de altura, são desenvolvidas em rochas siliciclásticas das formações Nhamundá 
(Siluriano inferior) e Manacapuru (Siluriano superiorDevoniano inferior). Os estudos morfológico e estrutural dessas feições indicam que a maioria dessas quedas de água originaram-se por neotectônica quaternária e encontram-se instaladas em escarpas de falhas normais NESW. Ocorrem, ainda, com menor freqüência, cachoeiras evoluídas a partir de feições pseudocársticas.

A origem das cachoeiras de Presidente Figueiredo provavelmente remonta ao Neógeno, quando a região estava sujeita aos processos de lateritização associados a um clima úmido em densa cobertura vegetal. Tais condições favoreceram o desenvolvimento de cavernas nos quartzoarenitos da Formação Nhamundá. Posteriormente, durante o Quaternário, a região foi afetada por falhas normais NE-SW que deslocaram perfis lateríticos, rios e igarapés, originando as cachoeiras. Esses fenômenos climáticos e tectônicos proporcionaram uma intensa dissecação do relevo da região, indicado pelo recuo das escarpas de falha e pelo desmantelamento de cavernas, responsável pela configuração morfológica atual da região.

Palavras-chave: cachoeiras, Amazônia ocidental, Tectônica quaternária, pseudocarste.

\section{REFERENCES}

AleXANDrowicz Z. 1994. Geologically controlled waterfall types in the Outer Carpathians. Geomorphology 9: 155-165.

Ängeby O. 1951. Pothole erosion in recent water falls. Lund Stud Geogr A 2: 1-34.

BARCHA SF AND ARID FM. 1975. Origem das cachoeiras da Bacia do Alto Paraná. Rev Bras Geoc 5: 120-135.

Christofoletti A. 1974. Geomorfologia. 4.ed. São Paulo: Edgard Blücher, p. 46.

Christofoletti A. 1981. Geomorfologia fluvial: o canal fluvial. 1.ed. São Paulo: Edgard Blücher, p. $1-243$.

Coelho GL. 1994. Relatório final de estágio na área de palinologia. Rio de Janeiro, PETROBRÁS CENPES/DIVEX/SEBIPE, 22p. (Relatório interno).

Coltrinari L. 1994. A Terra. São Paulo: Ática, p. 36.

Corrêa Neto AV and Dutra G. 1997. A Província
Espeleológica Quartzítica de Andrelândia, sudeste de Minas Gerais. In: Congresso Brasileiro de Espeleologia, 24., Ouro Preto. Anais..., Ouro Preto, SEE/SBE, 1964. p. 57-64.

Costa JBS, Hasui Y, Bemerguy RL, Borges MS, Costa AR, Travassos W, Mioto JA and Igreja HLS. 1993. Aspectos fundamentais de Neotectônica da Amazônia brasileira. In: Simpósio Internacional do Quaternário da Amazônia, 1., Manaus. Resumos..., Manaus, FUA/INPA/UNESCO, 1993. p. 103-105.

Costa JBS, Bemerguy RL, Hasui Y, Borges MS, Ferreira Júnior CRP, Bezerra PEL, Costa ML AND FERnANDES JMG. 1996. Neotectônica da região Amazônica: aspectos tectônicos, geomorfológicos e deposicionais. Geonomos 4: 23-24.

Costa ML. 1991. Aspectos geológicos dos lateritos da Amazônia. Rev Bras Geoc 21: 146-160.

Costa ML, Horbe AMC, Horbe MA, Teixeira JT AND Costa WAMC. 1988. A Região bauxítica do Pitinga (AM). In: Congresso Brasileiro de Geologia, 35., Belém. Anais..., Belém, SBG, 1998. 1: 256269.

Costa RCR, Filho NT and Oliveira AAB. 1978. Geomorfologia. In: Brasil. Projeto RADAMBRASIL. Folha SA.20 Manaus. Rio de Janeiro: CPRM/DNPM, 18: 167-244. (Levantamento de Recursos Naturais).

Cunha PRC, Gonzaga FG, Coutinho LFC And FeiJó FJ. 1994. Bacia do Amazonas. Bol Geoc Petrobrás 8: 47-55.

Deffontaines B And Chorowicz J. 1991. Principles of drainage basin analysis from multisource data: application to the structural analysis of the Zaire Basin. Tectonophysics 194: 237-263.

Dino R, Silva OB and Abrahão D. 1999. Palynological and stratigraphic characterization of the Cretaceous strata from the Alter do Chão Formation, Amazonas Basin. In: Simpósio sobre o Cretáceo do Brasil and Simpósio sobre el Cretácico de América del Sur 5., Serra Negra. Boletim..., Serra Negra, 1999. p. 557-565.

Fernandes Filho LA, Costa ML and Costa JBS. 
1997. Registros neotectônicos nos lateritos de Manaus - Amazonas. Geociências 16: 9-33.

Franzinelli E ANd Igreja HLS. 1990. Utilização do sensoriamento remoto na investigação da área do baixo Rio Negro e Grande Manaus. In: Simpósio Brasileiro de Sensoriamento Remoto, 6., Rio de Janeiro. Anais..., Rio de Janeiro, INPE/SELPER/ISPRS/SBC, 1990. 3: 641-648.

Franzinelli E and PiUci J. 1988. Evidências de neotectonismo na Bacia Amazônica. In: Congresso LatinoAmericano de Geologia, 7., Belém. Anais..., Belém, SBG, 1988. p. 80-90.

GRAHN Y. 1991. Ordovician chitinozoa and biostratigraphy of Brazil. Geobios 25: 703-723.

GraHn Y. 1992. Revision of Silurian and Devonian strata of Brazil. Palinology 16: 35-61.

Holmes A. 1966. Geología física. 5.ed. Barcelona: Omega SA, p. 90-113.

Horbe AMC, Costa ML, Fernandes Filho LA and Oliveira ZC. 1997. Caracterização de latossolos desenvolvidos sobre crostas alumino-ferruginosas lateríticas com base na mineralogia e elementostraço. In: Congresso Brasileiro de Geoquímica, 6., Salvador. Anais..., Salvador, SBGq, 1997. 2: 547549.

Horbe AMC, Nogueira ACR, Horbe MA, Costa ML AND Suguio K. 2000. A lateritização na gênese das superfícies de aplanamento da região de Presidente Figueiredo-Vila de Balbina, nordeste do Amazonas In: Contribuições à Geologia da Amazônia. Belém: FINEP/SBG-Núcleo Norte. (in press).

KARMAnN I. 1986. Caracterização geral e aspectos genéticos da gruta arenítica Refúgio do Maroaga, AM-02. Espeleo-Tema 15: 9-18.

Martini J. 1987. Karst features in quartzite of South Africa. Karstologia 9: 45-52.

Nascimento DA, Mauro CA and Garcia MGL. 1976. Geomorfologia. In: Brasil. Projeto RADAMBRASIL. Folha SA.21 Santarém. Rio de Janeiro: CPRM/DNPM, 10: 131-181. (Levantamentos de Recursos Naturais).

NogueIra ACR AND SoAres EAA. 1996. Fácies se- dimentares da Formação Prosperança, Proterozóico Superior da Bacia do Amazonas, ao norte da cidade de Manaus. In: Simpósio de Geologia da Amazônia, 5., Belém. Resumos..., Belém, SBG, 1996. p. 214216.

Nogueira ACR, Souza V And SoAres EAA. 1997. Contribuição à tectônica cenozóica da região de Presidente Figueiredo, norte de Manaus-AM. In: Simpósio Nacional de Estudos Tectônicos, 6., Pirinópolis. Resumos..., Pirinópolis, SBG, 1997. p. 123-125.

Philbrick SS. 1970. Horizontal configuration and the rate of erosion of Niagara Falls. Geol Soc Am Bull 81(12): 3723-3731

Robinson DA AND William RBG. 1989. Polygonal cracking of sandstone at Fontainebleau, France. Z Geomorphol NF 33(1): 59-72.

SAntos JOS. 1984. A Parte setentrional do cráton Amazônico (Escudo das Guianas) e a Bacia Amazônica. In: Schobbenhaus $\mathrm{C}$ et al. (Coord.). Geologia do Brasil. Brasília: DNPM, p. 57-88.

Schobbenhaus C And CAmpos DA. 1984. A Evolução da plataforma sul-americana no Brasil e suas principais concentrações minerais. In: SchobBEnhaus $\mathrm{C}$ et al. (Coord.). Geologia do Brasil. Brasília: DNPM, p. 9-49.

SchWARZBACH KVM. 1967. Islandische Wasserfälle und eine genetische systematik der wasserfälle überhaupt. Z Geomorphol NF 11(4): 377-417.

Silva CL, Costa SS and Carvalho JS. 1994. Um estudo preliminar neotectônico na cidade da ManausAM. In: Simpósio Nacional de Estudos Tectônicos, 5., Rio Claro. Resumos..., SBG, 1994. p. 438-439.

Soares EAA, Truckenbrodt W ANd Nogueira ACR. 1998. Depósitos glácio-costeiros da Formação Nhamundá, Siluriano inferior da Bacia dos Amazonas, Região de Presidente Figueiredo-AM. In: Congresso Brasileiro de Geologia, 40., Belo Horizonte. Bol Resumos..., Belo Horizonte, SBG, 1998. p. 99.

Sternberg HO. 1950. Vales tectônicos na planície amazônica? Rev Bras Geogr 12(4): 3-26.

Suguio K and Bigarella JJ. 1990. Ambientes fluviais. 2.ed. Florianópolis: Ed UFSC/UFPr, p. 1-83. 
URBANI F. 1986. Notes on the origin of caves in precambrian quartzites of Roraima Group, Venezuela. Interciência 11: 298-300.

White WB, JefFerson GL and Haman JF. 1966. Quartzite karst in southeastern Venezuela. International Journal of Speleology 2: 309-314.
Young RW. 1985. Waterfalls: form and processes. Z Geomorphol NF suppl 55: 81-95.

Young RW. 1986. Tower karst in sandstone: Bungle Bungle massif, Northeastern Australia. Z Geomorph N F 30: 189-202. 